\title{
Antioxidant and Nephroprotective Effects of Okra Pods Extract (Abelmoschus esculentus L.) against Lead Acetate-Induced Toxicity in Mice
}

\author{
Sri Puji Astuti Wahyuningsih ${ }^{(D)},{ }^{1}$ Nadyatul Ilma Indah Savira, \\ Devinta Wahyu Anggraini, ${ }^{1}$ Dwi Winarni, ${ }^{1}$ Listijani Suhargo, ${ }^{1}$ Baskara Wiku Adi Kusuma, \\ Faradita Nindyasari, ${ }^{1}$ Nur Setianingsih, ${ }^{1}$ and Adamu Ayubu Mwendolwa ${ }^{1}$ \\ ${ }^{1}$ Department of Biology, Faculty of Science and Technology, Airlangga University, Surabaya 60115, Indonesia \\ ${ }^{2}$ Faculty of Medicine, Airlangga University, Surabaya 60286, Indonesia \\ ${ }^{3}$ Biology Education, Faculty of Teacher Training and Education, University of Jember, Jember, East Java 68121, Indonesia \\ Correspondence should be addressed to Sri Puji Astuti Wahyuningsih; sri-p-a-w@fst.unair.ac.id
}

Received 7 November 2019; Revised 31 January 2020; Accepted 24 February 2020; Published 31 March 2020

Academic Editor: Kent L. Erickson

Copyright (c) 2020 Sri Puji Astuti Wahyuningsih et al. This is an open access article distributed under the Creative Commons Attribution License, which permits unrestricted use, distribution, and reproduction in any medium, provided the original work is properly cited.

\begin{abstract}
In this study, we determine the curative effects of okra pods (Abelmoschus esculentus L.) extract against lead acetate toxicity in mice kidney. $n$-Hexane, ethyl acetate, and methanol solvent were used for extracting okra pods. The role of the extract as an antioxidant was tested by DPPH and FRAP methods. The methanol extract was used for experiments in animals. A total of 30 male $\mathrm{BALB} / \mathrm{c}$ mice were randomly divided into six equal groups: normal control, negative control (lead-induced), and treatment groups (lead-induced for 28 days and administration of methanol extract at doses of 50, 100, 200, and $400 \mathrm{mg} / \mathrm{kg}$ BW for the 28 days). The following were analyzed in all groups: activity of the antioxidant enzymes, namely, superoxide dismutase (SOD) and catalase (CAT); oxidant level, namely, malondialdehyde (MDA) and nitric oxide (NO); and markers of kidney injury, namely, blood urea nitrogen (BUN) and creatinine (Cre). Kidney histopathology was also evaluated. This study showed that the methanol extract showed the highest antioxidant activity $\left(\mathrm{IC}_{50}\right.$ is $35.21 \mu \mathrm{g} / \mathrm{mL}$, and FRAP is $\left.57.58 \mu \mathrm{M} \mathrm{Fe}^{2+/} \mathrm{g}\right)$. The CAT and SOD activities increased significantly in okra-treated groups $(P<0.05)$. The okra administration groups experienced a significant decrease in MDA, NO, BUN, and Cre levels $(P<0.05)$. Thickness of the epithelial proximal tubule, diameter of the proximal tubule, and percentage of necrotic cells in proximal tubule decreased, but the diameter ratio of glomerular Bowman's capsule in mice treated with okra was optimally improved and repaired like normal control $(P<0.05)$. The results of this study reveal that methanol extract has a very strong antioxidant effect and can reduce the influence of toxicity induced by lead acetate in mice kidney.
\end{abstract}

\section{Introduction}

Lead is a ubiquitous environmental toxin that has been detected in almost all phases of biological systems [1]. Lead results from the burning vehicle fuel, settles into the soil, and is absorbed by the plant, so food can be the source of lead exposure. Lead can also be found in old pipes, yellow faucets, and solder pipes that will contaminate water. Some researchers believe that lead in the water and pipeline systems results in lead poisoning $[2,3]$. The kidney is one of the targeted sites of $\mathrm{Pb}$-toxicity for being a major route of excretion from the body and facilitates kidney damage via oxidative stress and lipid peroxidation (LP). Acute lead poisoning (blood lead levels $>80-100 \mu \mathrm{g} / \mathrm{dL}$ ) disrupts both proximal tubular structure and function [4].

Lead may play a major role in generating oxidative stress. Several studies have reported that lead has induced oxidative stress [5]. It is believed that lead generated reactive oxygen species (ROS) and decreased the function of antioxidant enzymes; for example, it reduced glutathione (GSH) level 
and superoxide dismutase (SOD) activity [6,7]. Lead acetate exposure doses of $50 \mathrm{mg} / \mathrm{kg} \mathrm{BW}$ and $100 \mathrm{mg} / \mathrm{kg} \mathrm{BW}$ caused oxidative stress and changed the expressions of apoptosisrelated proteins in mouse liver [8]. Administration of lead acetate decreased SOD and CAT activity and increased LP in mice's kidneys [9]. The release of malondialdehyde (MDA) is an indicator of LP [10].

So far, the administration of chelating agents is generally approved for lead poisoning [11]. Natural antioxidant administration may be effective in the treatment of lead poisoning. Surprisingly, it has not been closely investigated. Some published studies have discovered that natural antioxidants have an important role in abating oxidative stress caused by lead in animals [12]. In the present study, we focused on the extract of okra pods as a natural antioxidant.

Okra, Abelmoschus esculentus L. is a flowering plant valued for its edible fruits and belongs to the family of Malvaceae that is often consumed as a nutritional enhancer in different countries [13]. It has been revealed that both okra fruit and seeds contain flavonoid, polyphenol, catechin, quercetin, procyanidin, and ascorbic acid functioning as antioxidants [14-16].

This study aims to investigate the antioxidant and nephroprotective potential of okra pods extract in lead acetate exposed mice. The antioxidant and nephroprotective effects of okra pods extract were measured in vitro by 2, 2-diphenyl-picrylhydrazyl (DPPH) assay and ferric reducing antioxidant power (FRAP) assay. We determined the effect of the extract in vivo by measuring the NO and MDA level, the enzyme activities of SOD and CAT, the nephroprotective effect in kidney injury (level of BUN and Cre), the thickness of epithelial proximal tubule, the diameter of the proximal tubule, the percentage of necrotic cells in the proximal tubule, and the diameter ratio of glomerular Bowman's capsule.

\section{Materials and Methods}

2.1. Chemicals and Reagents. $n$-Hexane and ethyl acetate were used in solvent extraction and were purchased from Fulltime Chemical (Anhui, China), and methanol was purchased from Merck (Darmstadt, Germany). DPPH was purchased from Sigma-Aldrich (MO, USA). TPTZ (2, 4, 6-tri(2pyridyl)-s-triazine) was purchased from Oxford Laboratory (Maharashtra, India). MDA assay kit (Bioxytech ${ }^{\circledR}$ MDA-586) was purchased from Oxis International, Inc. (Portland, OR, USA). Sulfanilic acid and N-(1-naphthyl)-ethylenediamine were purchased from Merck (Darmstadt, Germany) and used for the NO assay. SOD and CAT assay kit were purchased from BioAssay Systems (Hayward, USA). BUN FS Cat. No. 13101 9910021 and Creatinine FS Cat. No. 117119910021 were purchased from DiaSys. For kidney histology preparations, we used neutral-buffered formalin (10\%), paraffin, hematoxylineosin, ethanol (70\%, 80\%, 96\%, absolute), EtOH acid, xylene, and Entellan mounting medium.

2.2. Plant Extract. Okra pods were collected from the traditional market in Surabaya, Indonesia, in January 2018 and identified by Dr. Junairiah, a botanist of the Department of Biology, Faculty of Science and Technology, Airlangga University. Okra pods were cleaned, sun-dried, and pulverized using a mechanical grinder. About $200 \mathrm{~g}$ of dried powder was extracted by reflux. In the first extraction, we used $n$-hexane (thrice, $24 \mathrm{~h}$ each time), and the solvents of each were collected. Ethyl acetate was used to extract the residue (thrice, $24 \mathrm{~h}$ each time), and the solvents of each were collected. Then the residue was extracted thrice $(24 \mathrm{~h}$ each time) using methanol, and the solvents of each were collected. Those solvents were evaporated using a rotary evaporator and were freeze-dried. Hence, there were three extracts ( $n$-hexane extract, ethyl acetate extract, and methanol extract) [17].

2.3. DPPH Radical Scavenging Assay. The stable DPPH free radical scavenging activity of $n$-hexane extract, ethyl acetate extract, and methanol extract was measured by Prieto's method. Each extract was prepared in various concentrations $(200,150,100,75,50,35,25,15,12.5,10,6.25$, and $3.125 \mu \mathrm{g} / \mathrm{mL}$ ). Then $100 \mu \mathrm{L}$ of each concentration was mixed with $100 \mu \mathrm{L}$ of $50 \mu \mathrm{g} / \mathrm{mL}$ DPPH solution. After $30 \mathrm{~min}$ incubation, the absorbance was observed at $\lambda 517 \mathrm{~nm}$ by UV/V is microplate spectrophotometer (Thermo Scientific ${ }^{\mathrm{TM}}$ Multiskan $^{\mathrm{TM}}$ GO). DPPH, $50 \mu \mathrm{g} / \mathrm{mL}$, was used as DPPH absorbance and methanol as a blank. Analysis of each concentration of the extract was performed in duplicate. The percentage of radical scavenging was determined by using the following formula.

$$
\% \text { DPPH scavenging }=\frac{(\text { Abs DPPH }- \text { Abs blank })-(\text { Abs sample }- \text { Abs blank })}{(\text { Abs DPPH }- \text { Abs sample })} \times 100 \%
$$

Based on its calibration curve, the inhibitory concentration $50 \%\left(\mathrm{IC}_{50}\right)$ of DPPH scavenging activity of each extract could be calculated.

2.4. Ferric Reducing Antioxidant Power (FRAP) Assay. The principle of this method is based on the reduction of a ferric-TPTZ complex to its ferrous, colored form in the presence of antioxidants. Briefly, the FRAP reagent was prepared in acetate buffer $300 \mathrm{mM}$ (pH 3.6) with 1 volume of $10 \mathrm{~mm}$ TPTZ solution in $40 \mathrm{~mm}$ hydrochloric acid and 1 volume of $20 \mathrm{mM}$ ferric chloride $\left(\mathrm{FeCl}_{3} \cdot 6 \mathrm{H}_{2} \mathrm{O}\right)$ [18]. Aliquots of $100 \mu \mathrm{L}$ sample supernatant were mixed with $900 \mu \mathrm{L}$ distilled $\mathrm{H}_{2} \mathrm{O}$ and $2 \mathrm{~mL}$ FRAP reagent. The absorbance of the reaction mixture at $593 \mathrm{~nm}$ was measured spectrophotometrically after incubation in the dark for $30 \mathrm{~min}$. The $0.001 \mathrm{M}$ ferrous sulfate 
$\left(\mathrm{FeSO}_{4} \cdot 7 \mathrm{H}_{2} \mathrm{O}\right)$ was used as the standard solution. The final result was expressed as the concentration of antioxidants having a ferric reducing ability equivalent to that of $0.001 \mathrm{M}$ $\mathrm{FeSO}_{4} \cdot 7 \mathrm{H}_{2} \mathrm{O}$ (regression of standard curve using ferrous sulfate $100-2000 \mu \mathrm{M})$. Analysis of each concentration of the extract was performed in duplicate, and the results were expressed in $\mu \mathrm{M} \mathrm{Fe}^{2+/} \mathrm{g}$ [19].

2.5. Animals and Experimental Design. Male BALB/c mice (8-10 weeks old, 30-40 g) were provided by the Animal Laboratory, Faculty of Pharmacy, Airlangga University, Indonesia. The animals were maintained in cages made of plastic with a lid made of woven wire cage at $20^{\circ} \mathrm{C}$, with $12^{\circ} \mathrm{h}$ light $/ 12^{\circ} \mathrm{h}$ dark cycle, fed, and watered ad libitum. All procedures involving animal care were approved by the Animal Care and Use Committee (ACUC) of Veterinary Faculty, Airlangga University, Indonesia, no. 714-KE. The mice were initially acclimatized to the experimental housing conditions and animal handlers for 7 days before all experiments to minimize handling stress during the test. Mice were randomly divided into six groups ( $K N$ : normal control without any treatment; $K-$ : negative control induced by lead acetate $75 \mathrm{mg} / \mathrm{kg}$ BW without methanol extract administration; $P 1, P 2, P 3$, and $P 4$ : methanol extract doses of 50, 100, 200 , and $400 \mathrm{mg} / \mathrm{kg} \mathrm{BW}$, respectively). Furthermore, mice were administered lead acetate orally for 28 days $(\mathrm{K}-, P 1, P 2$, $P 3$, and $P 4)$. On day 29 , mice were given the methanol extract orally for 28 days $(P 1, P 2, P 3$, and $P 4)$. In the $K N$ group, mice were given solvents only, namely, aquadest. Blood samples were collected $24 \mathrm{~h}$ after the last treatment. The blood was allowed to clot at room temperature and centrifuged at 3,000 rpm for $10 \mathrm{~min}$ to obtain serum, which was used for analyses.

2.6. SOD and CAT Activity Assay. The serum SOD activity was determined using EnzyChrom ${ }^{\mathrm{TM}}$ Superoxide Dismutase assay kit (ESOD-100) protocols from BioAssay System (Hayward, USA). The absorbance was measured at $\lambda 440 \mathrm{~nm}$ using a microplate UV/Vis spectrophotometer, while serum CAT activity was determined using the EnzyChrom ${ }^{\mathrm{TM}}$ Catalase assay kit (ECAT-100) protocols from BioAssay System (Hayward, USA). The absorbance was measured at $\lambda$ $570 \mathrm{~nm}$ using a microplate UV/Vis spectrophotometer.

2.7. Measurement of MDA and NO Levels. The level of MDA serum samples was analyzed using the Bioxytech ${ }^{\circledR}$ MDA586 spectrophotometric assay kit according to the manufacturer's protocol. Briefly, the serum sample, probucol, and diluted $\mathrm{R} 1$ were mixed in a vortexing tube. The mixture was added to R2 and incubated at $45^{\circ} \mathrm{C}$ for $40 \mathrm{~min}$. The tube was centrifuged $(10,000 \mathrm{~g}, 10 \mathrm{~min})$, and the supernatant was measured at $\lambda 586 \mathrm{~nm}$ using a microplate $\mathrm{UV} / \mathrm{V}$ is spectrophotometer. To determine the NO concentration, the stable $\mathrm{NO}$ conversion product, nitrite $\left(\mathrm{NO}_{2}\right)$, was measured with the Griess reagent [17]. For the NO assay, we used the Griess system protocol. Briefly, $50 \mu \mathrm{L}$ the serum was prepared in $1.5 \mathrm{~mL}$ microtube. $100 \mu \mathrm{L}$ Griess reagent I (sulfanilic acid in $2.5 \%$ phosphoric acid) and $100 \mu \mathrm{L}$ Griess reagent II (N-(1-naphthyl)-ethylenediamine in $2.5 \%$ phosphoric acid) were added to the serum. After $10-15$ min incubation at room temperature, optical density values were read at $540 \mathrm{~nm}$. Nitric oxide concentrations (M) were known after putting optical density values in the standard nitrite regression equation.

2.8. Measurement of BUN and Cre Levels. The level of BUN in serum was analyzed by Urea FS kits and Creatinine FS kits from DiaSys according to the manufacturer's protocol. The absorbance was measured using UV/Vis spectrophotometer at $340 \mathrm{~nm}$ for the BUN level and $492 \mathrm{~nm}$ for the Cre level.

2.9. Histopathological Study. The isolated kidney was washed using normal saline, fixed at $10 \%$ formal saline, dehydrated in ascending grades of alcohol, and embedded in paraffin wax. Sections were cut at a thickness of $4 \mu \mathrm{m}$. Staining was done by hematoxylin and eosin (H\&E). The section fields were examined under a light microscope. Furthermore, the thickness of the epithelial proximal tubule, the diameter of the proximal tubule, the percentage of necrotic cells in the proximal tubule, and diameter ratio of glomerular-Bowman's capsule were measured.

2.10. Statistical Analysis. Statistical data analysis was performed by one-way analysis of variance (ANOVA) followed by Duncan's post hoc test. All analyses were performed using IBM SPSS Statistics 24 software. The results were reported as the mean \pm standard deviation $(\mathrm{M} \pm \mathrm{SD})$ of five repeats. $P<0.05$ was considered statistically significant.

\section{Results and Discussion}

3.1. Antioxidant Activity. The free radical scavenging activity of all the samples of okra pods extracts is presented in Table 1. DPPH free radicals dissolved in methanol and absorbed at $\lambda 517 \mathrm{~nm}$. Colors of DPPH would be changed from purple to yellow when the free radicals are scavenged by antioxidants. The methanol extract showed the highest antioxidant activity with an $\mathrm{IC}_{50}$ value of about $35.21 \mu \mathrm{g} / \mathrm{mL}$, while ethyl acetate and $n$-hexane extract showed the lowest antioxidant activity with an $\mathrm{IC}_{50}$ value of 181.09 and $104.06 \mu \mathrm{g} / \mathrm{mL}$. The FRAP assay can rank the reducing power and the antioxidant potential. The highest ability to reduce $\mathrm{Fe}^{3+}$ to $\mathrm{Fe}^{2}+$ was found in the methanol extract $(57.58 \mu \mathrm{M}$ $\left.\mathrm{Fe}^{2+1} \mathrm{~g}\right)$. It means that methanol extract has stronger reducing power than $n$-hexane extract $\left(57.13 \mu \mathrm{M} \mathrm{Fe} e^{2+l} \mathrm{~g}\right)$ and ethyl acetate extract $\left(49.64 \mu \mathrm{M} \mathrm{Fe}^{2+/} \mathrm{g}\right)$.

The scavenging activity against DPPH free radical has been widely used to determine the antioxidant activity of plant extract [20]. Sample with $\mathrm{IC}_{50}$ lower than $50 \mu \mathrm{g} / \mathrm{mL}$ can be classified as a very strong antioxidant, $50-100 \mu \mathrm{g} / \mathrm{mL}$ as strong, $101-150 \mu \mathrm{g} / \mathrm{mL}$ as medium, and greater than $150 \mu \mathrm{g} /$ $\mathrm{mL}$ as weak [21]. The results of the DPPH assay in this study showed that the methanol extract has the lowest $\mathrm{IC}_{50}$ value $(35.21 \mu \mathrm{g} / \mathrm{mL})$ which indicated the best free radical 
TABLE 1: Result of antioxidant activity from DPPH and FRAP assays of various okra pods extracts.

\begin{tabular}{lcc}
\hline Sample extract & $\mathrm{IC}_{50}$ DPPH assay $(\mu \mathrm{g} / \mathrm{mL})$ & $\mathrm{FRAP}^{\text {assay }}\left(\mu \mathrm{M}\right.$ Fe $\left.{ }^{2+/} \mathrm{g}\right)$ \\
\hline$n$-Hexane extract & 104.06 & 57.13 \\
Ethyl acetate extract & 181.09 & 49.64 \\
Methanolic extract & 35.21 & 57.58 \\
\hline
\end{tabular}

scavenging activity and very strong antioxidant activity because methanol can dissolve the main active compounds such as quercetin, catechin, and vitamin, whereas $n$-hexane extract has medium antioxidant activity and ethyl acetate extract has weak antioxidant activity. DPPH values of okra pods in this study are better than those reported for okra seeds by a study from Ghana. The IC50 values for the sample infusions ranged from 127.800 to $405.667 \mu \mathrm{g} / \mathrm{ml}$. The undefatted samples ranged between 239.750 and $637.000 \mu \mathrm{g} /$ $\mathrm{ml}$, and the defatted samples had IC50 values ranging from 28.714 to $338.333 \mu \mathrm{g} / \mathrm{ml}$ [22].

The same thing happens when doing a FRAP test. The alcohol and ethyl acetate extracts from okra seeds contained flavonoids of $2.3328 \pm 0.008$ and $3.9082 \pm 0.01 \mathrm{mg}$ quercetin equivalent/g plant material. Both extracts are also found in rutin [23]. The ethanol extract okra seeds contain phenolics, flavonoids, total polysaccharide, and isoquercetin, while none of the four were found in $n$ hexane extract [24]. My other research showed that the total phenolic levels of okra pods in methanol extract are $12.92 \mathrm{mg}$ gallic acid equivalent (GAE)/g plant material, and the flavonoid level is $5.68 \mathrm{mg}$ quercetin equivalent/g plant material [25]. The methanol extract has a higher ability to reduce $\mathrm{Fe}^{3+}$ to $\mathrm{Fe}^{2+}$. Based on the $\mathrm{DPPH}$ and FRAP assays results, methanol extract was used to treat experimental animals with various concentrations (50, 100, 200, and $400 \mathrm{mg} / \mathrm{kg} \mathrm{BW).}$

This study also showed the antioxidant activity of methanol okra pods extract against lead acetate-induced toxicity in mice. In the in vivo antioxidant activity assay of methanol okra extract, we used the experimental animals to determine the kidney toxicity caused by lead acetate. Dose of exposure to lead acetate $75 \mathrm{mg} / \mathrm{kg} \mathrm{BW}$ was chosen according to $\mathrm{Xu}$ et al. [8]. Parameter of toxicity could be measured from the activity of antioxidant enzymes (SOD and CAT), oxidant levels, such as $\mathrm{NO}$ and MDA, biochemical parameters of kidney function (BUN and Cre levels), and also histopathology of the kidney.

\subsection{The Effect of Methanol Extract of Okra Pods on SOD and} CAT Activity. SOD and CAT activities are presented in Figure 1. The administration of methanol extract of okra pods restores normal SOD activity, except in group $P 2$, which is given methanol extract okra pods at $100 \mathrm{mg} / \mathrm{kg} \mathrm{BW}$. The SOD activity in $P 2$ was significantly increased compared to normal and negative controls $(P<0.05)$, whereas CAT activity in negative controls was significantly lower than normal controls $(P<0.05)$. The administration of methanol extract of okra pods in groups $P 1, P 3$, and $P 4$ has not been able to restore normal CAT activity $(P>0.05)$, but administration of okra extract at $100 \mathrm{mg} / \mathrm{kg} \mathrm{BW}$ can increase and improve CAT activity as normal.

Lead could be an inhibitor of the SOD enzyme, causing reduction in the activities of both SOD [26] and CAT [27]. Contrary to expectation, this study showed that SOD activity in the lead-treated group was not increased significantly. This result was the same as that of Vaziri [20]. A possible explanation for this might be that the dose of lead was low. Furthermore, the superoxide might be the factor of enhancement of SOD activity. According to Ercal et al. [17], lead caused an increase in superoxide and other reactive oxygen species compounds. However, administration of the methanol okra extract ameliorated SOD activity, exceeding normal. The antioxidant compound of this extract might have reduced superoxide. In another result, it is reported that CAT activity was decreased in lead-treated group. This result is likely to be related to lead as an inhibitor of CAT and $\mathrm{H}_{2} \mathrm{O}_{2}$. Treatments of the methanol okra extract did not restore CAT activity to normal levels, but administration of $100 \mathrm{mg} / \mathrm{kg}$ BW methanol okra extract enhanced CAT activity compared to the lead-treated group. As mentioned in the literature, quercetin and other flavonoids inactivate the generation of ROS and terminate the radical chain reaction [18].

\subsection{The Effect of Methanol Extract of Okra Pods on NO Level.} The results of the experimental data on NO levels are displayed in Figure 2. Nitric oxide level was determined by nitrite $\left(\mathrm{NO}_{2}\right)$ level, which interacted directly with sulfanilic acid under acidic conditions and was then revealed after diazotization with $\mathrm{N}$-(1-naphthyl)ethylenediamine. From Figure 2, it can be seen that the NO level in the negative control (K-group) was significantly increased compared to the normal control $(P<0.05)$. The administration of methanol okra pods extracts restored NO level to normal. No significant differences were found among methanol okra pods extract treatment groups $(P>0.05)$.

Based on the results of this study, NO levels in all groups treated with okra pods were significantly lower than those in the negative control. This result was similar to those of Barbosa et al. who stated that several plants as antioxidants had strong inhibitory activity on NO production in cells [28]. In the study, nitrite concentration in plasma of leadtreated mice was higher than normal. It reflects NO synthase activity [29, 30]. Lead exposure may significantly improve endothelial NO production [8]. Nitric acid can cause damage to proteins, lipids, and deoxyribonucleic acid (DNA) either directly or after interaction with superoxide [31]. The administration of methanol extract of okra pods showed the depletion of NO level and restored it to normal. 


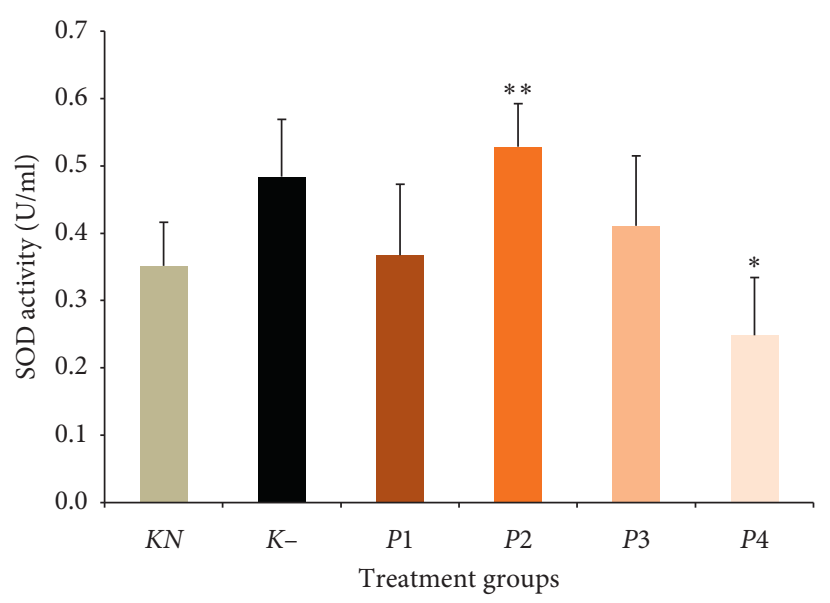

(a)

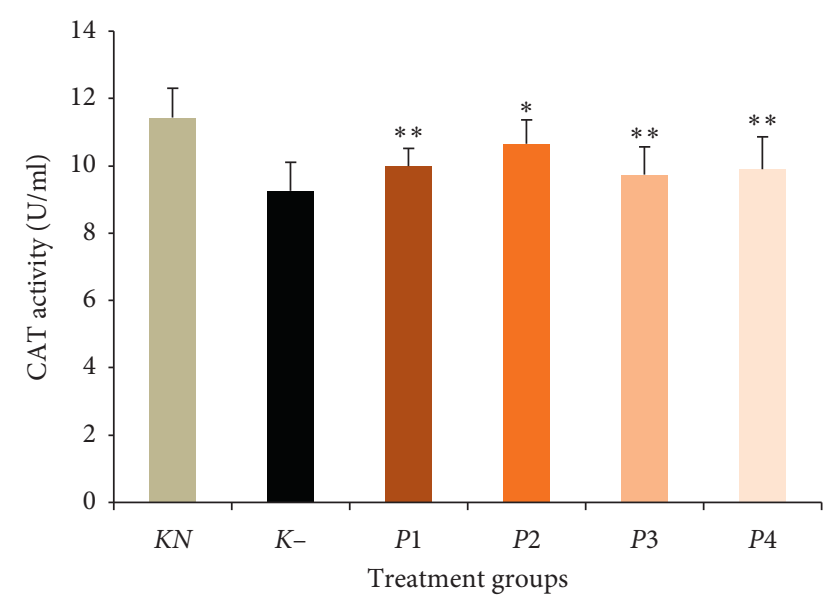

(b)

FIGURE 1: Effect of methanol extract of okra pods on both superoxide dismutase (SOD) and catalase (CAT) activity in lead acetate-induced mice. Values are as expressed as mean \pm standard deviation $(n=5) .{ }^{*} P<0.05$ shows significant differences in $\mathrm{K}-.{ }^{* *} P<0.05$ shows significant differences in $K N$, confidence interval $95 \%$. $K N$ : normal control, $K-$ : negative control. $P 1, P 2, P 3$, and $P 4$ were treated with 50,100 , 200 , and $400 \mathrm{mg} / \mathrm{kg}$ BW methanol extract of okra pods, respectively.

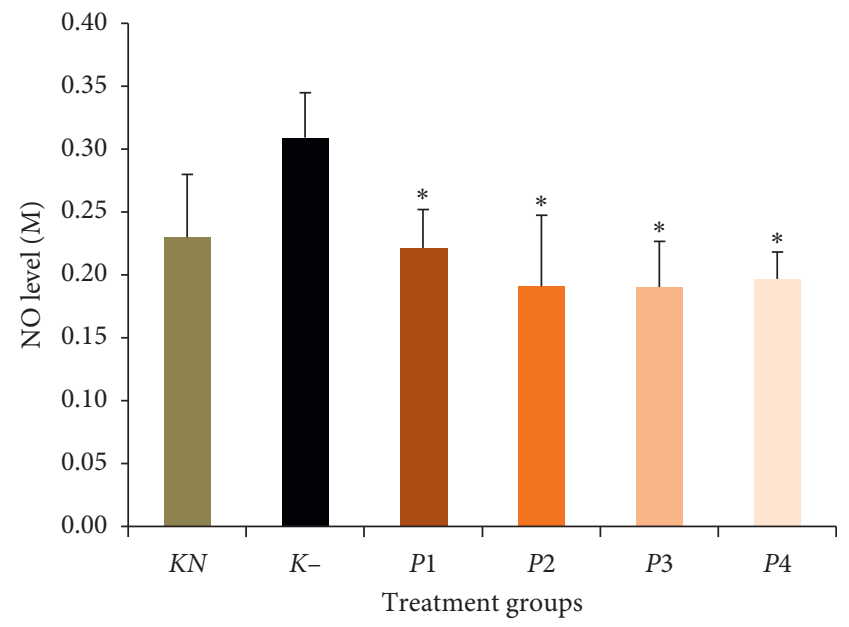

FIGURE 2: Effect of methanol extract of okra pods on nitric oxide (NO) level in lead acetate-induced mice. Values are as expressed as mean \pm standard deviation $(n=5) .{ }^{*} P<0.05$ shows significant differences in $K-$, confidence interval $95 \%$. $K N$ : normal control, $K-$ : negative control. $P 1, P 2, P 3$, and $P 4$ were treated with 50, 100, 200 , and $400 \mathrm{mg} / \mathrm{kg}$ BW methanol extract of okra pods, respectively.

\subsection{The Effect of Methanol Extract of Okra Pods on MDA Level.} Figure 3 presents the results obtained from the analysis of the MDA level. Malondialdehyde as stress oxidative marker of cell shows LP. It can be seen from Figure 3 that the lead-treated group showed the highest MDA level $(129.36 \pm 19.2 \mu \mathrm{M})$ and it was significantly increased by $72 \%$ compared to normal $(P<0.05)$. The MDA level of all treatments was significantly lower than the negative control $(P<0.05)$. Both $P 3$ and $P 4$ groups have the same MDA level as normal group $(P>0.05)$, but this is not true for both $P 1$ and $P 2$ groups. The $P 1$ group, treated with okra methanol extract $50 \mathrm{mg} / \mathrm{kg} \mathrm{BW}$, were unable to return NO levels to normal. However, in group $P 2$, the

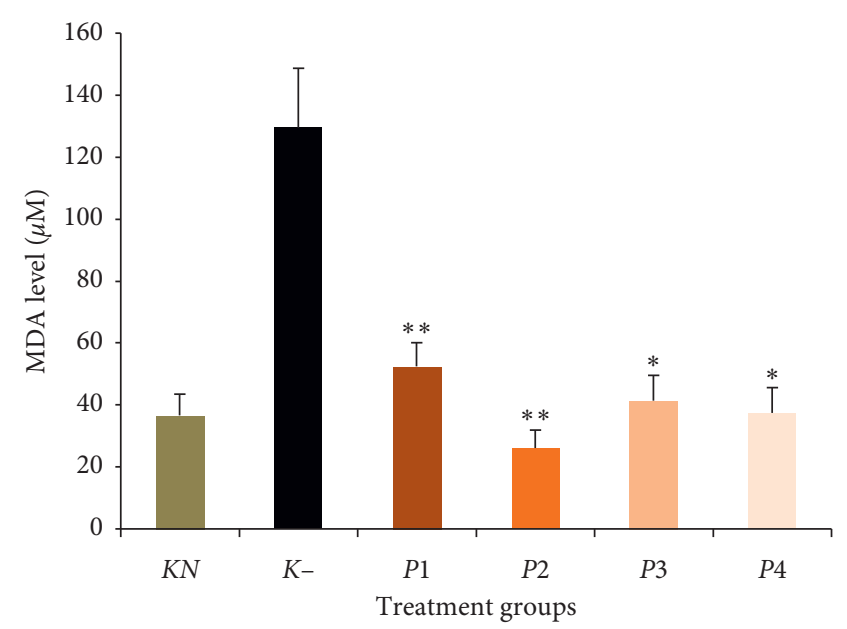

FIGURE 3: Effect of methanol extract of okra pods on malondialdehyde (MDA) level in lead acetate-induced mice. Values are as expressed as mean \pm standard deviation $(n=5) .{ }^{*} P<0.05$ shows significant differences with $K-,{ }^{* *} P<0.05$ shows significant differences in $K N$ and $\mathrm{K}$-, confidence interval 95\%. $K N$ : normal control, $K-$ : negative control. $P 1, P 2, P 3$, and $P 4$ were treated with $50,100,200$, and $400 \mathrm{mg} / \mathrm{kg}$ BW methanol extract of okra pods, respectively.

MDA level significantly decreased compared to the normal control group.

Lead is known to produce oxidative damage in cells by enhancing LP. Lead causes oxidative stress by stimulating the production of ROS. Reactive oxygen species attack lipids containing carbon-carbon double bond(s), especially polyunsaturated fatty acids (PUFAs) [32]. Malondialdehyde is a major reactive aldehyde resulting from LP and becoming a widely accepted biomarker [9]. This study suggested that lead administration caused a significant increase in the level of MDA serum, $72 \%$, compared to normal. Meanwhile, the 
administration of methanol extract from okra pods significantly decreased MDA levels. A study by Liu et al. also stated that quercetin could decrease LP in lead-treated rat liver [33]. Quercetin is one of the antioxidant compounds in the pods extract of $A$. esculentus $[34,35]$. Other studies have demonstrated that extract of okra fruit and seeds contains quercetin [36]. Antioxidant and metal chelating properties of quercetin depend on multiple hydroxyl groups of its chemical structure [37]. These hydroxyl groups along with the carboxyl group stabilize free radicals by donating electrons [38].

\subsection{The Effect of Methanol Extract of Okra Pods on BUN and} Creatinine Levels. The result of the experimental data on biochemical parameters in this study is measuring BUN and creatinine levels. The administration of methanol extract of okra pods significantly decreased BUN levels in $P 1, P 2$, and $P 3$ groups and creatinine levels in $P 4$ group $(P<0.05)$. Both BUN and Cre levels are displayed in Figure 4.

Cellular damage of kidney structure can decrease kidney function. Blood urea nitrogen and Cre levels are biochemical parameters of the kidney function. High levels of both BUN and creatinine were found in groups treated with lead acetate. This result was caused by kidney damage. This is similar to the result of Sudjarwo et al. [39] who reported that the lead acetate treatment significantly induced BUN and creatinine in serum. Our result indicated that methanol extract has a nephroprotective activity against lead acetate, as the treatment at doses of 50,100, 200, and $400 \mathrm{mg} / \mathrm{kg} \mathrm{BW}$ can reduce $\mathrm{BUN}$ and Cre levels.

3.6. The Effect of Methanol Extract of Okra Pods on Nephrotoxicity Kidney. Histopathological examination of the kidney tissue of mice that received distilled water (normal control group) showed normal nephrotic tissue. When compared with control mice $(K N)$, the lead acetate-induced mice $(K-)$ exhibited both swelling and necrotic cells in kidney section. Treatment with the methanol extract of okra pods $(P 1, P 2, P 3$, and $P 4)$ showed kidney healing and less degree of cellular damage (Figure 5). In parallel to biochemical observation, the histopathological studies demonstrated an improvement in the kidney structure. These results are consistent with the histopathological findings of the kidney tissue from the tested mice. Furthermore, kidney tissue is further observed in the proximal tubule and the Glomerulus-Bowman capsule to measure the degree of nephrotoxicity of the kidney.

Moreover, the thickness of the epithelium, the diameter and necrotic cells of proximal tubule, and the diameter ratio of glomerular-Bowman's capsule are displayed in Figure 6. Changes in glomerular filtration greatly affect the dynamics and function of Bowman's capsules. Bowman's capsule volume has been extensively studied to maintain normal kidney function [40]. We used morphometric approaches to analyze the diameter of Bowman capsules and investigated the related factors with normal renal function. Among the cells, proximal tubules are more susceptible to $\mathrm{Pb}$ induced cellular damage followed by apoptosis [4]. Proximal tubule hypertrophy can be a homeostatic response to a reduced nephron number since the maximal tubular size is limited by the dimensions (luminal diameter and tubular length) that create low enough resistance to allow tubular fluid flow for adequate reabsorption [41].

It can be seen that the epithelial thickness and the diameter and percentage of necrotic cells of proximal tubule in negative control were significantly increased compared to normal control $(P<0.05)$. Furthermore, the diameter ratio of glomerular Bowman's capsule of negative control was significantly decreased $(P<0.05)$. The administration of the methanol extract of okra pods significantly decreased the thickness of the epithelial proximal tubule in the P4 group. Okra also significantly decreased the diameter of the proximal tubule and percentage of necrotic cells in both $P 3$ and $P 4$ groups. It also significantly increased the diameter ratio of glomerular diameter-Bowman's capsule in $P 1, P 2, P 3$, and $P 4$ groups.

Stress oxidative can cause cell damage by LP in the plasma membrane, protein modification via lead binding with sulfhydryl mediators of amino acids, and DNA mutation [42-44]. One of the potential effects of high-level lead exposure is renal injury and nephropathy. Prolonged lead exposure at lower plasma levels can cause nephrotoxicity. The most affected segment of kidney in induced renal injury is the proximal tubule [45]. Based on this result, we know that the thickness of the epithelium and the diameter and percentage of necrotic cells in proximal tubule were significantly increased, but the diameter ratio of glomerular Bowman's capsule was significantly decreased after treatment with lead acetate. Rana et al. reported that $\mathrm{Pb}$ hinders the integrity of the cell junctions (tight junction) and modifies cellular structure. Altered polarity and vectorial transport of epithelial cells could result from atypical cell-cell junction structure following reduced renal proximal tubule lumen and microvilli loss [4].

The epithelial thickness and the diameter of the proximal tubule are directly proportional. Enhancement of thickness of the epithelium and the diameter of the proximal tubule is caused by cell swelling, which is a change in cell environment or a way of cell adaptation to repair damage. $\mathrm{Mi}$ croscopically cell injury results in cell swelling, sometimes followed by compression or displacement position of cell organelle [46]. Percentage of necrotic cells indicated that cells have been damaged. The percentage of necrotic cells increased significantly after lead acetate-induced toxicity. Other that than, extract methanol of okra pods can repair the damage of these cells by their antioxidant activity. Based on this result, treatment of methanol extract can decrease cell damage, and then there is a decrease in the epithelial thickness and the diameter and percentage of necrotic cells in the proximal tubule effectively at dose $50 \mathrm{mg} / \mathrm{kg} \mathrm{BW}$ and optimally at doses 200 and $400 \mathrm{mg} / \mathrm{kg}$ BW. Kotyk et al. reported that the glomerular diameter increased in fructosesupplemented rats when compared to controls [47]. Furthermore, the effect of methanol extract of okra pods can improve the immune system, which is at dose of $100 \mathrm{mg} / \mathrm{kg}$ BW could increase NK cell activity and IFN- $\gamma$ levels [48]. Thus, many immune cells like macrophages and neutrophils increase to repair and eliminate cell debris. 200 and $400 \mathrm{mg} / \mathrm{kg} \mathrm{BW}$ are doses for repair toward normal. 


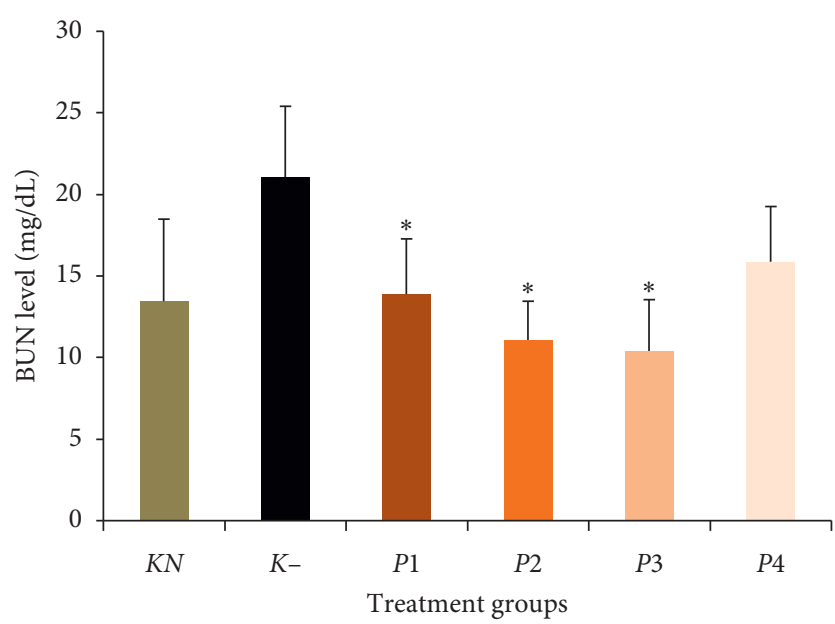

(a)

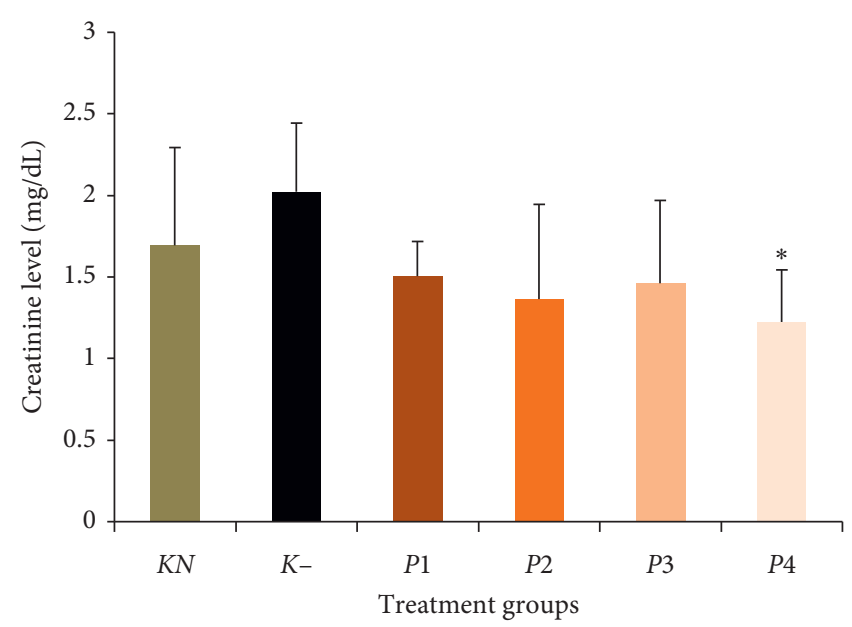

(b)

FIGURE 4: Effect of methanol extract of okra pods on blood urea nitrogen (BUN) and creatinine (Cre) levels. Values are as expressed as mean \pm standard deviation $(n=5) .{ }^{*} P<0.05$ shows significant differences in $K$-, confidence interval $95 \%$. $K N$ : normal control, $K-:$ negative control. $P 1, P 2, P 3$, and $P 4$ were treated with $50,100,200$, and $400 \mathrm{mg} / \mathrm{kg} \mathrm{BW}$ methanol extract of okra pods, respectively.

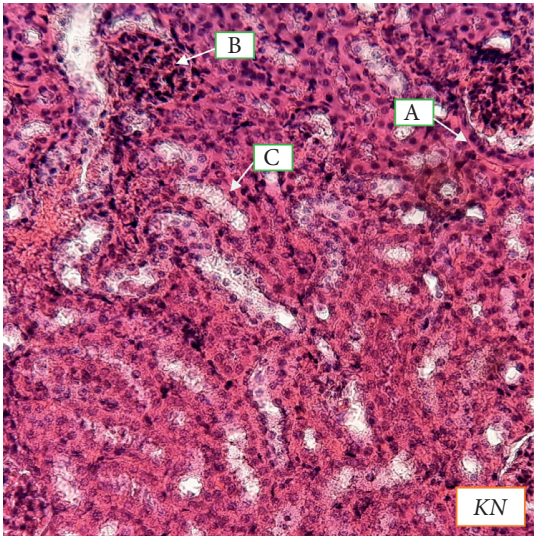

(a)

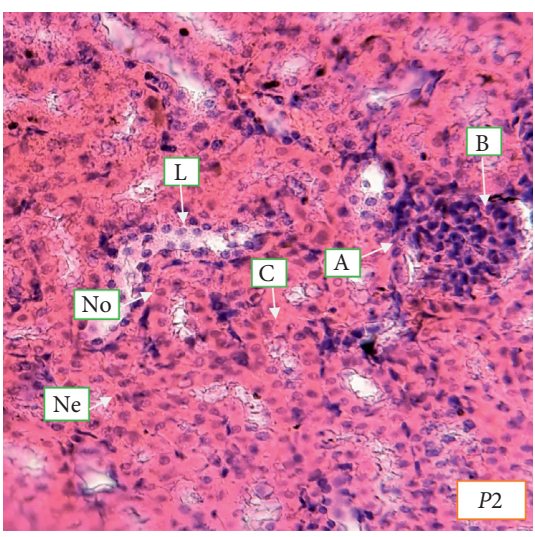

(d)

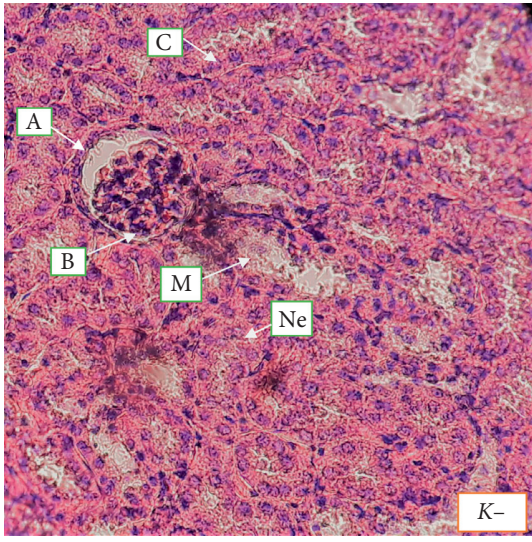

(b)

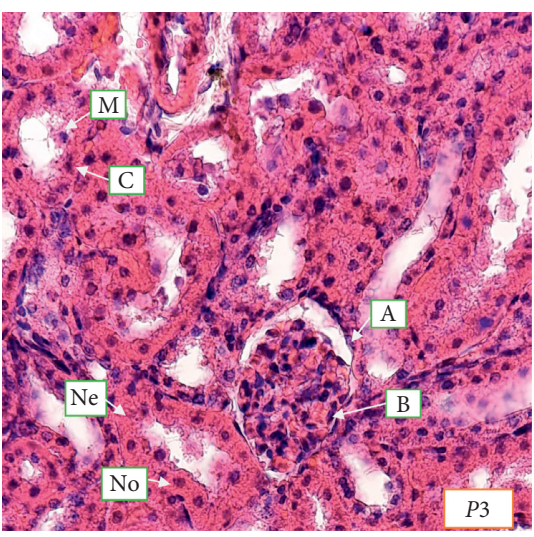

(e)

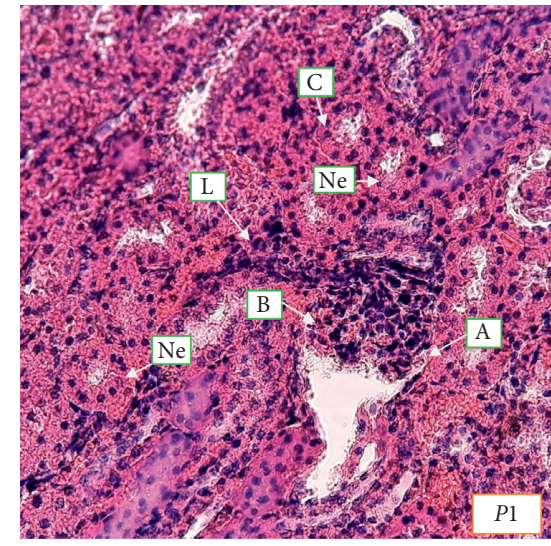

(c)

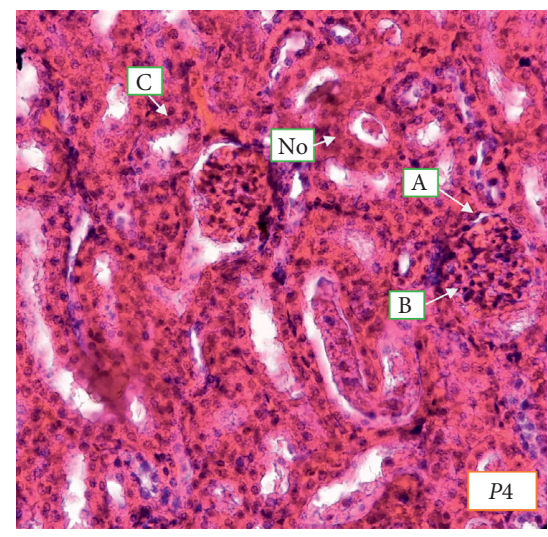

(f)

FIgURE 5: Histology of the kidney ( $40 \times$ objectives, scale bar $50 \mu \mathrm{m}) . K N$ : normal control, $K-$ : negative control. $P 1, P 2, P 3$, and $P 4$ were treated with 50,100, 200, and $400 \mathrm{mg} / \mathrm{kg}$ BW methanolic extract of okra pods, respectively. A: Bowman's capsule, B: glomerular, C: proximal tubule, Ne: necrosis cell, No: normal cell, M: macrophage, L: polymorphonuclear cells. 


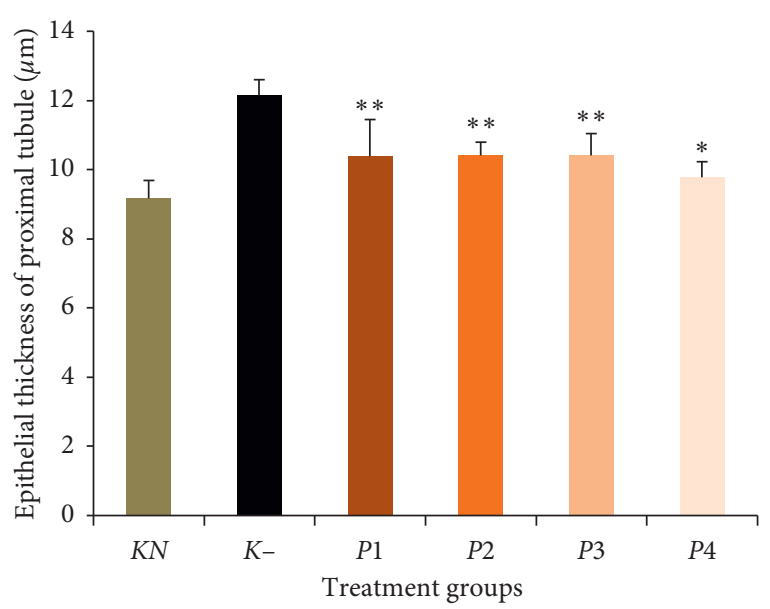

(a)

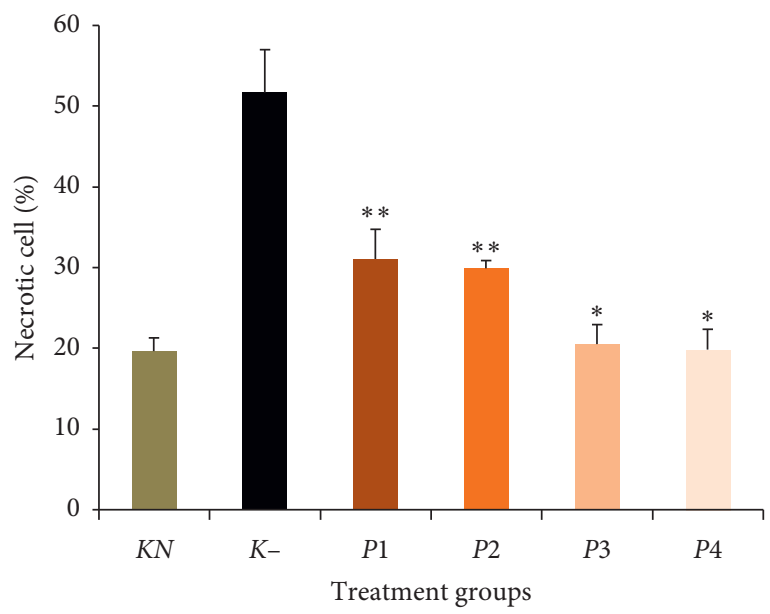

(c)

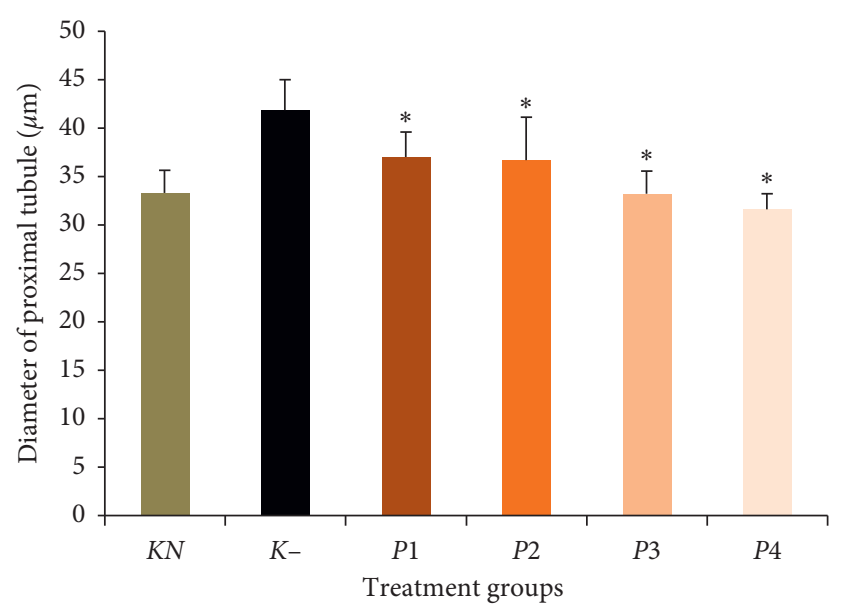

(b)

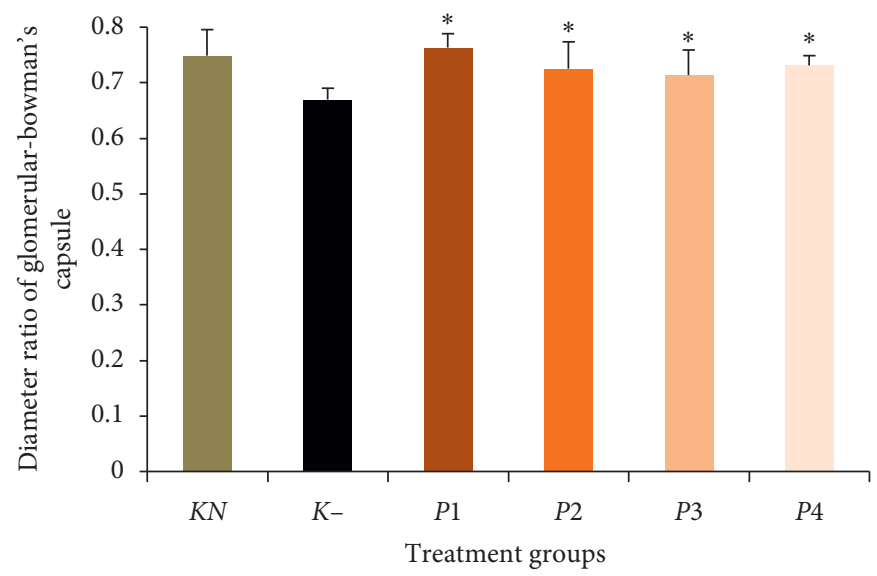

(d)

FIGURE 6: Effect of methanol extract of okra pods on kidney histology (thickness of epithelial proximal tubule, diameter of the proximal tubule, percentage of necrotic cells, and diameter ratio of glomerular Bowman's capsule) in lead acetate-treated mice. Values are as expressed as mean \pm standard deviation $(n=5) .{ }^{*} P<0.05$ shows significant differences in $K-,{ }^{* *} P<0.05$ shows significant differences in $K N$ and $K-$, confidence interval $95 \%$. $K N$ : normal control, $K-$ : negative control. $P 1, P 2, P 3$, and $P 4$ were treated with $50,100,200$, and $400 \mathrm{mg} / \mathrm{kg}$ BW methanol extract of okra pods, respectively.

\section{Conclusions}

We concluded that the methanol extract of okra pods can attenuate lead toxicity by increasing levels of SOD and CAT and decreasing levels of MDA, NO, BUN, and Cre. Okra pods succeeded in stimulating the histology of kidney like thickness of the epithelial proximal tubule, diameter of the proximal tubule, percentage of necrotic cells, and ratio diameter of glomerular Bowman's capsule toward the normal. Okra has nephroprotective potential against the toxicity of the acetate lead in mice. This suggests that the methanol extract of okra pods has antioxidant activity and plays a protective role against lead-induced toxicity.

\section{Abbreviations}

DPPH: 2, 2-Diphenyl-picrylhydrazyl

FRAP: Ferric reducing antioxidant power

SOD: Superoxide dismutase

CAT: Catalase
MDA: Malondialdehyde

NO: $\quad$ Nitric oxide

BUN: Blood urea nitrogen

Cre: Creatinine.

\section{Data Availability}

All data arising from this study are included within the article.

\section{Ethical Approval}

Ethical approval was obtained from the Animal Care and Use Committee (ACUC) of Veterinary Faculty, Airlangga University, Indonesia, no. 714-KE.

\section{Conflicts of Interest}

The authors declare that there are no conflicts of interest regarding the publication of this paper. 


\section{Acknowledgments}

This study was financially supported by a grant (no. 122/ SP2H/PTNBH/DRPM/2018) from the Ministry of Research and Higher Education, Indonesia.

\section{References}

[1] M. U. Gani, M. S. I. Siddiqui, M. H. O. Rashid et al., "Effect of lead acetate alone and in combination with whole milk (Star ship) on body growth and liver functions in an experimentally induced lead toxicity in rat," Asian Journal of Medical and Biological Research, vol. 2, no. 2, pp. 183-189, 2016.

[2] M. S. H. Khan, M. Mostofa, M. S. Jahan et al., "Effect of garlic and vitamin B-complex in lead acetate induced toxicities in mice," Bangladesh Journal of Veterinary Medicine, vol. 6, no. 2, pp. 203-210, 2008.

[3] D. D. Chiras, Environmental Science, Jones and Bartlett Publishers, Burlington, MA, USA, 9th edition, 2013.

[4] M. N. Rana, J. Tangpong, and M. M. Rahman, "Toxicodynamics of Lead, Cadmium, Mercury and Arsenic- induced kidney toxicity and treatment strategy: a mini review," Toxicology Reports, vol. 5, pp. 704-713, 2018.

[5] G. Flora, D. Gupta, and A. Tiwari, "Toxicity of lead: a review with recent updates," Interdisciplinary Toxicology, vol. 5, no. 2, pp. 47-58, 2012.

[6] W. H. El-Tantawy, "Antioxidant effects of Spirulina supplement against lead acetate-induced hepatic injury in rats," Traditional and Complementary Medicine, vol. 6, no. 4, pp. 327-331, 2015.

[7] A. Kasperczyk, G. Machnik, M. Dobrakowski M et al., "Gene expression and activity of antioxidant enzymes in the blood cells of workers who were occupationally exposed to lead," Toxicology, vol. 301, no. 1-3, pp. 79-84, 2012.

[8] J. Xu, L.-j. Lian, C. Wu, X.-f. Wang, W.-y. Fu, and L.-h. Xu, "Lead induces oxidative stress, DNA damage and alteration of p53, Bax and Bcl-2 expressions in mice," Food and Chemical Toxicology, vol. 46, no. 5, pp. 1488-1494, 2008.

[9] Z. Singh, P. Chadha, and S. Sharma, "Evaluation of oxidative stress and genotoxicity in battery manufacturing workers occupationally exposed to lead," Toxicology International, vol. 20, no. 1, pp. 95-100, 2013.

[10] A. Rahal, A. Kumar, V. Singh et al., "Oxidative stress, prooxidants, and antioxidants: the interplay," BoiMed Research International, vol. 2014, Article ID 761264, 19 pages, 2014.

[11] H. Gurer and N. Ercal, "Can antioxidants be beneficial in the treatment of lead poisoning?" Free Radical Biology and Medicine, vol. 29, no. 10, pp. 927-945, 2000.

[12] B. S. Okediran, K. T. Biobaku, F. H. Olaifa, and A. J. Atata, "Haematological and antioxidant enzyme response to Lead toxicity in male Wistar rats," Ceylon Journal of Science, vol. 46, no. 2, pp. 31-37, 2017

[13] L. Hu, W. Yu, Y. Li, N. Prasad, and Z. Tang, "Antioxidant activity of extract and its major constituents from okra seed on rat hepatocytes injured by carbon tetrachloride," BioMed Research International, vol. 2014, Article ID 341291, 9 pages, 2014.

[14] P. Arapitsas, "Identification and quantification of polyphenolic compounds from okra seeds and skins," Food Chemistry, vol. 110, no. 4, pp. 1041-1045, 2008.

[15] P. Khomsug, W. Thongjaroe, N. Pakdeenaro, M. Suttajit, and P. Chantirati, "Antioxidative activities and phenolic content of extracts from okra (Abelmoschus esculentus L.)," Research Journal of Biological Sciences, vol. 5, no. 4, pp. 310-313, 2010.

[16] T. K. Lim, Edible Medicinal and Non-Medicinal Plants, Vol. 1, Springer Science and Business Media BV, Heidelberg, Germany, 2012.

[17] N. Ercal, H. Gurer-Orhan, and N. Aykin-Burns, "Toxic metals and oxidative stress part I: mechanisms involved in metalinduced oxidative damage," Current Topics in Medicinal Chemistry, vol. 1, no. 6, pp. 529-539, 2001.

[18] M. T. A GarciaandE and L. M. Gonzalez, "Toxic effects of perinatal lead exposure on the brain of rats: involvement of oxidative stress and the beneficial role of antioxidants," Food and Chemical Toxicology, vol. 46, no. 6, pp. 2089-2095, 2008.

[19] M. S. Blois, "Antioxidant determinations by the use of a stable free radical," Nature, vol. 181, no. 4617, pp. 1199-1200, 1958.

[20] N. D. Vaziri, "Mechanisms of lead-induced hypertension and cardiovascular disease," American Journal of Physiology-Heart and Circulatory Physiology, vol. 295, no. 2, pp. H454-H465, 2008.

[21] T. Sakai, "Biomarkers of lead exposure," Industrial Health, vol. 38, no. 2, pp. 127-142, 2000.

[22] J. O. Graham, J. K. Agbenorhevi, and F. M. Kpodo, "Total phenol content and antioxidant activity of okra seeds from different genotypes," American Journal of Food and Nutrition, vol. 5, no. 3, pp. 90-94, 2017.

[23] J. Patwardhan and P. Bhatt, "Flavonoids derived from Abelmoschus esculentus attenuates UV-B induced cell damage in human dermal fibroblasts through Nrf2-ARE pathway," Pharmacognosy Magazine, vol. 12, no. 2, pp. S129-S138, 2016.

[24] W. Chaemsawang, W. Prasongchean, K. I. Papadopoulos et al., "The effect of okra (Abelmoschus esculentus (L.) Moench) seed extraction human cancer cell lines delivered in its native form and loaded in polymeric micelles," Journal of Biomaterials, vol. 2019, Article ID 9404383, 13 pages, 2019.

[25] S. P. A. Wahyuningsih, D. Winarni, M. Pramudya et al., "Antioxidant potential of okra pods extract (Abelmoschus esculentus (L.) Moench," EPiC Series in Biological Sciences, 2019 in press.

[26] R. Zhang, Y. Niu, Y. Li et al., "Acute toxicity study of the interaction between titanium dioxide nanoparticles and lead acetate in mice," Environmental Toxicology and Pharmacology, vol. 30, no. 1, pp. 52-60, 2010.

[27] J. Wang, H. Zhu, Z. Yang, and Z. Liu, “Antioxidative effects of hesperetin against lead acetate-induced oxidative stress in rats," Indian Journal of Pharmacology, vol. 45, no. 4, pp. 4395-4398, 2013.

[28] F. Barbosa, J. T. Sertorio, R. F. Gerlach, and J. E. Tanus-Santos, "Clinical evidence for lead-induced inhibition of nitric oxide formation," Archives Of Toxicology, vol. 80, no. 12, pp. 811816, 2016.

[29] I. Fidrianny, H. Suhendy, and M. Insanu, "Correlation of phytochemical content with antioxidant potential of various sweet potato (Ipomoea batatas) in West Java, Indonesia," Asian Pacific Journal of Tropical Biomedicine, vol. 8, no. 1, pp. 25-30, 2018.

[30] Y. S. Chi, B. S. Cheon, and H. P. Kim, "Effect of wogonin, a plant flavone from Scutellaria radix, on the suppression of cyclooxygenase- 2 and the induction of inducible nitric oxide synthase in lipopolysaccharide-treated RAW 264.7 cells," Biochemical Pharmacology, vol. 61, no. 10, pp. 1195-1203, 2001.

[31] M. Hamzeh, F. Talebpour Amiri, S. Y. Beklar, and S. J. Hosseinimehr, "Nephroprotective effect of cerium oxide nanoparticles on cyclophosphamide-induced nephrotoxicity 
via anti-apoptotic and antioxidant properties in $\mathrm{BALB} / \mathrm{c}$ mice," Marmara Pharmaceutical Journal, vol. 22, no. 2, pp. 180-189, 2018.

[32] K. Saha, N. H. Lajis, D. A. Israf et al., "Evaluation of antioxidant and nitric oxide inhibitory activities of selected Malaysian medicinal plants," Journal of Ethnopharmacology, vol. 92, no. 2-3, pp. 263-267, 2004.

[33] C.-M. Liu, J.-Q. Ma, and Y.-Z. Sun, "Quercetin protects the rat kidney against oxidative stress-mediated DNA damage and apoptosis induced by lead," Environmental Toxicology and Pharmacology, vol. 30, no. 3, pp. 264-271, 2010.

[34] P. Kleinbongard, A. Dejam, T. Lauer et al., "Plasma nitrite concentrations reflect the degree of endothelial dysfunction in humans," Free Radical Biology and Medicine, vol. 40, no. 2, pp. 295-302, 2006.

[35] F. Xia, Y. Zhong, M. Li et al., "Antioxidant and anti-fatigue constituents of okra," Nutrients, vol. 7, no. 10, pp. 8846-8858, 2015.

[36] T. Lauer, M. Preik, T. Rassaf et al., "Plasma nitrite rather than nitrate reflects regional endothelial nitric oxide synthase activity but lacks intrinsic vasodilator action," Proceedings of the National Academy of Sciences of the USA, vol. 98, no. 22, pp. 12814-12819, 2001.

[37] G. R. Beecher, "Overview of dietary flavonoids: nomenclature, occurrence and intake," The Journal of Nutrition, vol. 133, no. 10, pp. 3248S-3254S, 2003.

[38] P. Kleinbongard, A. Dejam, T. Lauer et al., "Plasma nitrite reflects constitutive nitric oxide synthase activity in mammals," Free Radical Biology and Medicine, vol. 35, no. 7, pp. 790-796, 2003.

[39] S. A. Sudjarwo, K. Eraiko, G. Wardani, and E. Koerniasari, "Protective effects of piperine on lead acetate inducednephrotoxicity in rats," Iranian Journal of Basic Medical Sciences, vol. 20, no. 11, pp. 1227-1231, 2017.

[40] T. Sasaki, N. Tsuboi, K. Haruhara et al., "Bowman capsule volume and related factors in adults with normal renal function," Kidney International Reports, vol. 3, no. 2, pp. 314-320, 2018.

[41] R. L. Chevalier, "The proximal tubule is the primary target of injury and progression of kidney disease: role of the glomerulotubular junction," American Journal of PhysiologyRenal Physiology, vol. 311, no. 1, pp. F145-F161, 2016.

[42] M. K. Eberhardt, Reactive Oxygen Metabolites: Chemistry and Medical Consequences, CRC Press LLC, Boca Raton, FL, USA, 2001.

[43] D. S. Kumar, D. E. Tony, A. P. Kumar et al., "A review on Abelmoschus esculantus (okra)," International Research Journal of Pharmaceutical and Applied Sciences, vol. 3, no. 4, pp. 129-132, 2013.

[44] A. Ayala, M. F. Munoz, and S. Arguelles, "Lipid peroxidation: production, metabolism, signaling mechanisms of malondialdehyde and 4-hydroxy-2-nonenal," Oxidative Medicine and Cellular Longevity, vol. 2014, Article ID 360438, 31 pages, 2014.

[45] M. Shafiekhani, M. M. Ommati, N. Azarpira, R. Heidari, and A. A. Salarian, "Glycine supplementation mitigates lead-induced renal injury in mice," Journal of Experimental Pharmacology, vol. 11, pp. 15-22, 2019.

[46] W. Haschek, C. Rousseaux, and M. Wallig, Handbook of Toxicology Pathology, Academic Press, Cambridge, MA, USA, 3rd edition, 2013.

[47] T. Kotyk, N. Dey, A. S. Ashour et al., "Measurement of glomerulus diameter and Bowman's space width of renal albino rats," Computer Methods and Programs in Biomedicine, vol. 126, pp. 143-153, 2016.

[48] S. P. A. Wahyuningsih, M. Pramudya, I. P. Putri et al., "Okra polysaccharides improves spleen weight and B-lymphocytes proliferation in mice infected by Staphylococcus aureus," Biosaintifika: Journal of Biology \& Biology Education, vol. 9, no. 3, pp. 460-465, 2017. 